\title{
Influence of Thyroid Function on Serum Bone Gla Protein
}

\author{
Masahiro YONEDA, Kensuke TAKATSUKI, Kazuyuki YaMAUCHI, Yutaka OISO, \\ Masaei KUROKAWA, AKitoshi KAWAKUBO, KaZuhiro IZUCHI, \\ Hiroshi TANAKA, Osamu KOZAWA, Yoshitaka MIURA, \\ *AKIO NAGASAKA, *TAKAKo OHYAMA \\ AND **AKIO TOMITA
}

First Department of Internal Medicine, Nagoya University School of Medicine, Tsurumai-cho, Showa-ku, Nagoya, 466

*Department of Internal Medicine, Fujita-Gakuen Health University School of Medicine, Toyoake, Aichi-ken 470-11

**Central Laboratory for Clinical Investigation, Aichi Medical University Nagakute-cho, Aichi-gun, Aichi-ken, 480-11

\begin{abstract}
The serum BGP level was assayed in patients with hyperthyroidism (untreated and remittent cases) and hypothyroidism. The mean serum BGP concentration was $9.7 \pm 0.90 \mathrm{ng} / \mathrm{ml}$ in 30 patients with untreated hyperthyroidism which was significantly higher than the $2.7 \pm 0.38 \mathrm{ng} / \mathrm{ml}$ in 15 remittent patients and $1.3 \pm 0.31 \mathrm{ng} / \mathrm{ml}$ in 13 patients with hypothyroidism $(\mathrm{p}<0.001, \mathrm{p}<$ 0.001). Serum BGP had a significant positive correlation with the concentrations of free triiodothyronine and alkaline phosphatase in the serum, while it had a significant negative correlation with serum PTH. In the patients with hypothyroidism, serum BGP increased significantly in parallel with increases in serum free triiodothyronine with thyroxine therapy. In the patients with hyperthyroidism, serum free triiodothyronine decreased significantly after the first month of methimazole treatment, and fluctuated within the normal range after two months. Serum alkaline phosphatase and BGP did not show significant changes "during the first six months of treatment, although they were eventually reduced significantly at the end of one year.

These results suggest that thyroid hormone directly stimulates the synthesis and secretion of BGP in existent osteoblasts and also acts on the bone remodeling cycle, therapy accelerating the rate of bone formation; the latter action may occur over a long period.
\end{abstract}

Serum bone $\gamma$-carboxyglutamic acid (Gla) containing protein (bone gla protein: BGP)

Received July 27, 1987

Correspodence to : MASAHIRO YONEDA M. D. First Department of Internal Medicine, Nagoya University School of Medicine, Tsurumaicho, Showa-ku, Nagoya, 466 Japan is thought to be a sensitive and specific marker of bone turnover (Price et al., 1980). The serum concentration level has been studied in patients having various diseases with abnormality of bone metabolism, including primary hyperparathyroidism. The clinical usefulness of this assay has been 
reported (Price et al., 1980; Delmas et al., 1983 ; Yoneda et al., 1986).

Recently, it has been reported that patients with hyperthyroidism show high serum BGP concentrations that reflect abnormal bone metabolism (Orimo et al., 1984; Garrel et al., 1986; Lukert et al. 1968). However, the effects of thyroid hormone on serum BGP have not been clarified.

Here we studied the relationship of serum BGP to thyroid hormone and biochemical factors related to bone metabolism in patients at various stages of thyroid function to better understand the effects of thyroid hormone on serum BGP. In addition, we investigated changes in serum BGP following treatment of thyroid disorders.

Based on these data, we have attempted to clarify the effects of thyroid hormone on serum BGP.

\section{Materials and Methods}

Our subjects were 30 patients with untreated hyperthyroidism, 15 patients with remittent hyperthyroidism, and 13 patients with untreated hypothyroidism.

The diagnosis of hyperthyroidism was based on classic clinical criteria and confirmed by several thyroid function tests that included free thyroxine $\left(\mathrm{FT}_{4}\right)$, free triiodothyronine $\left(\mathrm{FT}_{3}\right)$, and elevated thyroid ${ }^{123} \mathbf{I}$ uptake. The patients with remittent hyperthyroidism were those who had maintained a normal thyroid hormone concentration for two years or more with a maintenance dose of the antithyroid drugs, and had a positive $\mathrm{T}_{3}$ suppression test. Hypothyroidism was diagnosed on the basis of clinical features and serum biochemical data $\left(\mathrm{FT}_{4}, \mathrm{FT}_{3}\right.$ and TSH).

Decreased renal function was not found in any patient. Sex difference and age distribution were comparable among the three groups.

All blood samples were collected while the subjects were fasting early in the morning to examine blood chemistry and assay the baseline concentrations of triiodothyronine $\left(\mathrm{T}_{3}\right), \mathrm{FT}_{3}$, $\mathrm{FT}_{4}$, parathyroid hormone (PTH) and BGP.
BGP was measured with a radioimmunassay kit (Immuno Nuclear Co., stillwater, Minnesota), The antibody used in this kit was obtained by immunizing rabbits against bovine BGP. The mean \pm S. E. value for serum BGP determined in normal adults by this procedure is $4.5 \pm 0.48$ $\mathrm{ng} / \mathrm{ml}$ and the normal range is $2.0-7.0 \mathrm{ng} / \mathrm{ml}$ (Yoneda et al., 1986).

PTH was measured by the previously described method of radioimmunoassay (Kawakubo et al., 1986). In this kit, the antibody specific for human PTH 43-68 was used (Middle region assay, Yamasa Shoyu Co., Ltd., Choshi). The normal range is $0.17-0.41 \mathrm{ng} / \mathrm{ml}$ for PTH.

$\mathrm{T}_{3}, \mathrm{FT}_{3}$ and $\mathrm{FT}_{4}$ were measured with the Dinabot T-3 RIAKIT II (Dainabot Co. Tokyo), Amerlex Free $T_{3}$ radioimmunoassay kit and Amerlex Free $T_{4}$ radioimmunoassay kit (Amersham International plc, U. K.) respectively. The normal range is $0.9-1.9 \mathrm{ng} / \mathrm{ml}$ for $\mathrm{T}_{3}, 2.4-6.0 \mathrm{pg} /$ $\mathrm{ml}$ for $\mathrm{FT}_{3}$ and $0.8-1.8 \mathrm{ng} / \mathrm{dl}$ for $\mathrm{FT}_{4}$ in the serum (Mitsuma et al., 1976; Kisamori et al., 1984; Mitsuma et al., 1981). The inter and intra-assay variations were less than $13 \%$.

Serum $\mathrm{Ca}, \mathrm{P}$, albumin (Alb) and ALP were measured with an autoanalyzer (Technicon SMAC Jr.). Serum Ca was corrected by Alb according to the formula of Payne (Payne et al., 1973). The normal range is $8.4-10.0 \mathrm{mg} / \mathrm{dl}$ for $\mathrm{Ca}, 2.9-4.5 \mathrm{mg}$ $/ \mathrm{dl}$ for $\mathrm{P}$ and $30-115 \mathrm{IU} / \mathrm{l}$ for ALP in the serum.

All data are given as the mean \pm S. E. and were assessed by Student's $t$-test and paired ttest for the significance of differences.

\section{Schedule of the clinical study was as following :}

1. Effects of methimazole therapy on serum BGP concentration in patients with hyperthyroidism.

Eight patients with hyperthyroidism were given orally $30 \mathrm{mg}$ of methimazole daily. Doses were decreased according to the thyroid function of individual patients. Blood samples were collected before and after 1, 2, 3, 6, and 12 months of treatment.

2. Effects of triiodothyronine $\left(\mathbf{T}_{3}\right)$ on serum BGP concentration in patients with remittent hyperthyroidism ( $T_{3}$ suppression test).

Fifteen patients with remittent hyperthyroidism were given orally $75 \mu \mathrm{g}$ of liothyronine sodium daily for 7 days. Blood samples were collected before and on the 7th day of treatment.

3. Effects of thyroxine $\left(\mathrm{T}_{4}\right)$ therapy on serum BGP 
concentration in patients with hypothyroidism.

Nine patients with hypothyroidism were given orally $25 \mu \mathrm{g}$ of levothyroxine daily. Doses were increased slowly according to the function of individual patients until they reached maintenance doses in all patients after three months of treatment. Blood samples were collected before and after 1, 2, and 3 months of treatment.

\section{Results}

Table 1 shows the laboratory data for

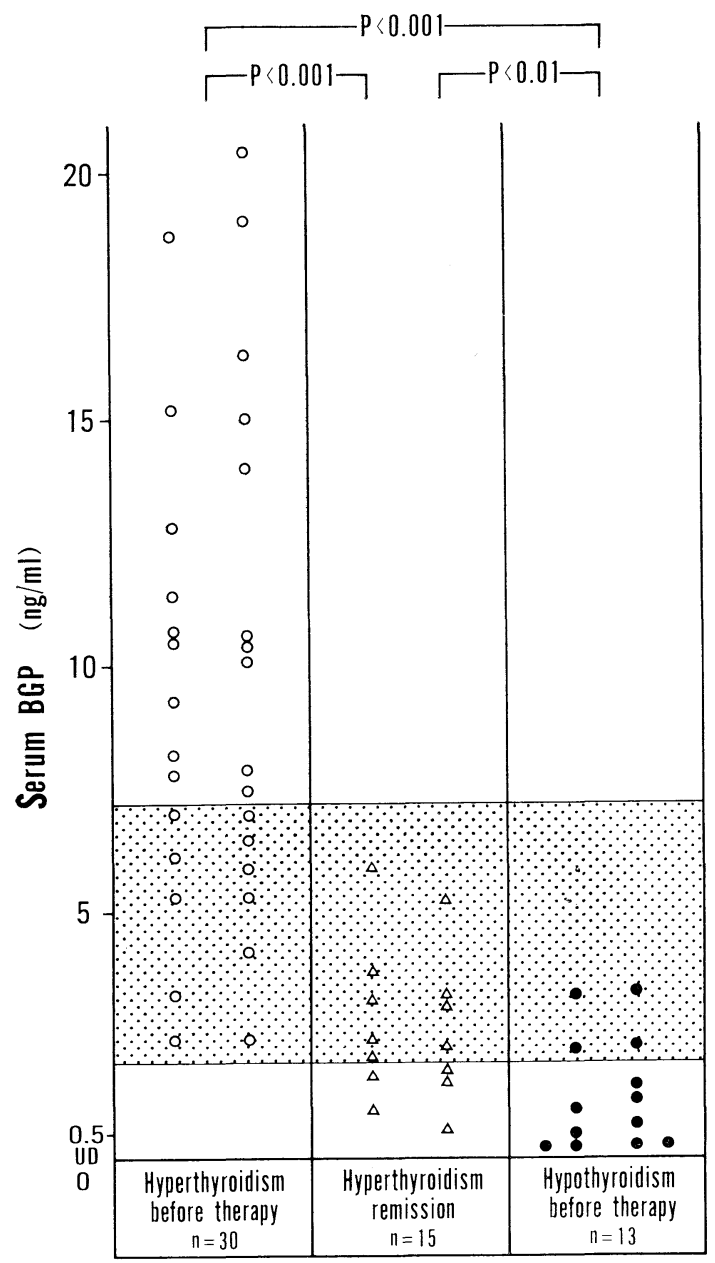

Fig. 1. Serum BGP in 30 patients with hyperthyroidism, 15 patients with remittent hyperthyroidism and 13 patients with hypothyoidism. Shaded area represents the value for the normal control $( \pm 2 S D)$.

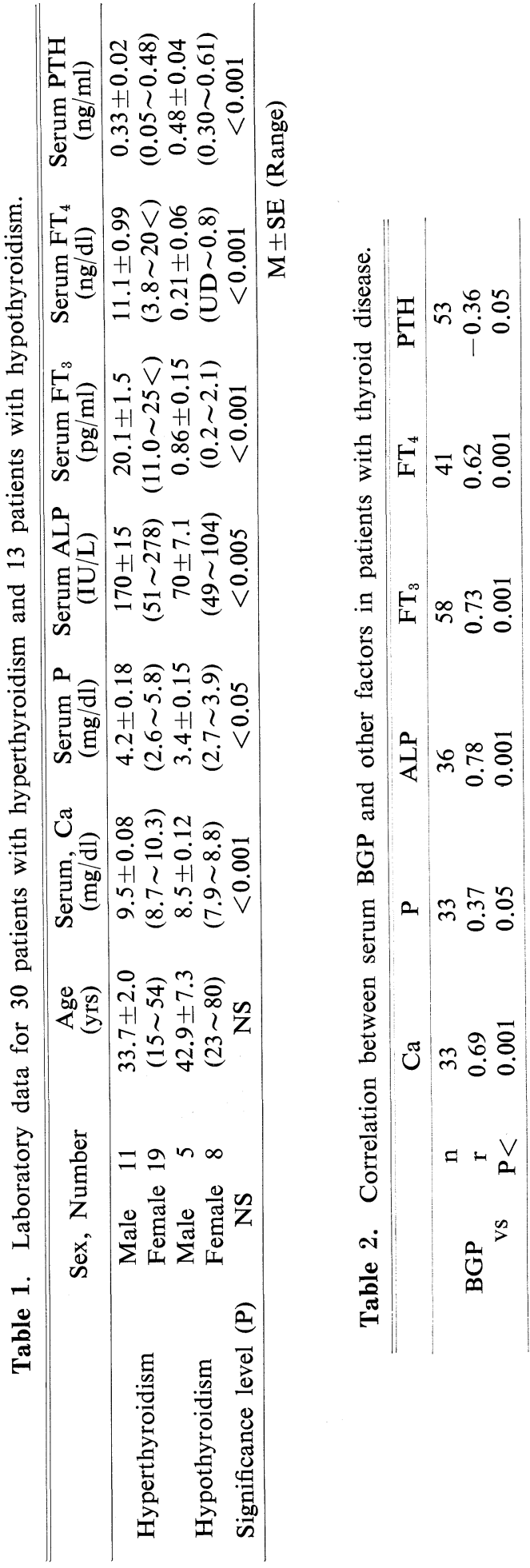


the patients with hyper- and hypothyroidism. The concentrations of $\mathrm{Ca}(\mathrm{p}<0.001), \mathrm{P}(\mathrm{p}<$ $0.05)$ and ALP $(p<0.005)$ in the serum were significantly higher in the patients with hyperthyroidism than in those with hypothyroidism. The serum PTH concentration was significantly lower $(p<0.001)$ in the patients with hyperthyroidism $(0.33$ $\pm 0.02 \mathrm{ng} / \mathrm{ml}$ ) than in the patients with hypothyroidism $(0.48 \pm 0.04 \mathrm{ng} / \mathrm{ml})$.

As shown in Fig. 1, the serum BGP concentration was significantly higher in the patients with hyperthyroidism $(9.7 \pm 0.90 \mathrm{ng} /$ $\mathrm{ml}$; range, 2.4-20.4), than in patients with remittent hyperthyroidism $(2.7 \pm 0.38 \mathrm{ng} / \mathrm{ml}$; range, $1.0-3.9, \mathrm{p}<0.001)$ or those with hypothyroidism $(1.3 \pm 0.31 \mathrm{ng} / \mathrm{mg}$; range, $U$. D.-3.4, $\mathrm{p}<0.001)$. The serum BGP concentration was significantly lower $(p<0.01)$ in the patients with hypothyroidism than in patients with remittent hyperthyroidism. Abnormally high values were found in 19 of the 30 patients with hyperthyroidism and abnormally low values in 9 of the 13 patients with hypothyroidism.
Table 2 shows the correlation of the serum BGP concentrations with other biochemical factors in the three groups. The serum BGP had a significant positive correlation with $\mathrm{Ca}(\mathrm{p}<0.001), \mathrm{P}(\mathrm{p}<0.05)$, ALP $(\mathrm{p}<0.001), \mathrm{FT}_{3}(\mathrm{p}<0.001)$ (Fig. 2) and $\mathrm{FT}_{4}$ $(p<0.001)$ in the serum, and a significant negative correlation with PTH $(\mathrm{p}<0.05)$.

Fig. 3 shows the changes in serum BGP and other biochemical parameters with methimazole therapy in the eight patients with hyperthyroidism. Serum $\mathrm{FT}_{3}$ decreased significantly $(\mathrm{p}<0.01)$ from $15.9 \pm 1.3 \mathrm{pg} / \mathrm{ml}$ before treatment to $8.4 \pm 1.9 \mathrm{pg} / \mathrm{ml}(\mathrm{p}<0.01)$ in one month and to $5.1 \pm 1.1 \mathrm{pg} / \mathrm{ml}(\mathrm{p}<$ 0.001 ) in two months, and an euthyroid state was maintained up to one year thereafter. The serum Ca concentration dropped significantly from $9.3 \pm 0.18 \mathrm{mg} / \mathrm{dl}$ before treatment to $8.6 \pm 0.18 \mathrm{mg} / \mathrm{dl}$ three months after treatment was started $(\mathrm{p}<0.05), 8.7 \pm$ $0.14 \mathrm{mg} / \mathrm{dl}$ after six months $(\mathrm{p}<0.05)$ and $8.7 \pm 0.06 \mathrm{mg} / \mathrm{dl}$ after one year $(\mathrm{p}<0.01)$. The seum PTH concentration rose significantly $(p<0.05)$ from $0.27 \pm 0.05 \mathrm{ng} / \mathrm{ml}$

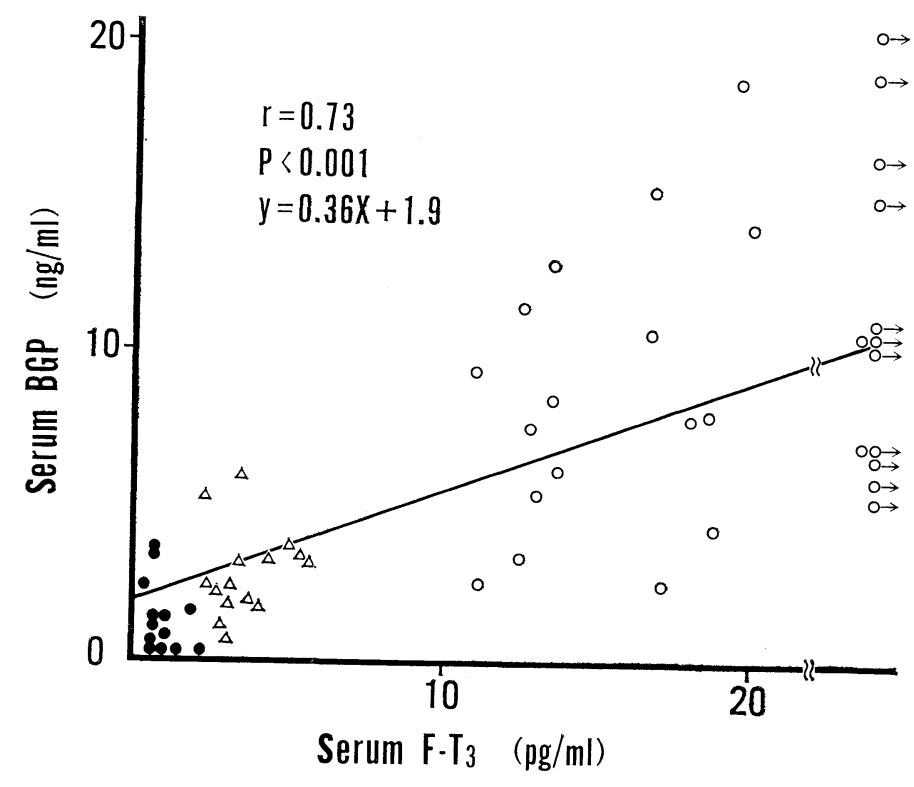

Fig. 2. The relationship between serum $\mathrm{F}-\mathrm{T}_{3}$ and BGP in 30 patients with hyperthyroidism $(\bigcirc), 15$ patients with remittent hyperthyroi$\operatorname{dism}(\triangle)$ and 13 patients with hypothyroidism (O). 
before treatment to $0.48 \pm 0.07 \mathrm{ng} / \mathrm{ml}$ three months after treatment was started. Serum ALP increased slightly 2-3 months after treatment was started from $160 \pm 22 \mathrm{IU} / \mathrm{L}$ before treatment, although the difference was not significant. It had decreased significantly $(\mathrm{p}<0.02)$ to $93 \pm 8.3 \mathrm{IU} / \mathrm{L}$ one year after treatment was started. Serum BGP did not show a significant change up to six months after treatment was started as compared to $8.7 \pm 1.1 \mathrm{ng} / \mathrm{ml}$ before treatment. It had decreased significantly $(\mathrm{p}<$
0.02 ) to $5.2 \pm 0.58 \mathrm{ng} / \mathrm{ml}$ one year after treatment was started.

In 15 patients with remittent hyperthyroidism who were given orally $75 \mu \mathrm{g}$ of $\mathrm{T}_{3}$ daily for a week for $\mathrm{T}_{3}$ suppression testing, serum $T_{3}$ increased significantly ( $p$ $<0.001$ ) from the pretreatment value of $1.3 \pm 0.06 \mathrm{ng} / \mathrm{ml}$ to $4.5 \pm 0.04 \mathrm{ng} / \mathrm{ml}$ at one week, while serum PTH was $0.45 \pm 0.04 \mathrm{ng} /$ $\mathrm{ml}$, showing no significant change compared to the pretreatment value of $0.49 \pm 0.04$ $\mathrm{ng} / \mathrm{ml}$. Serum BGP increased significantly

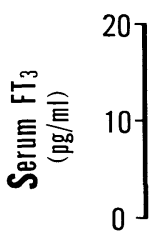

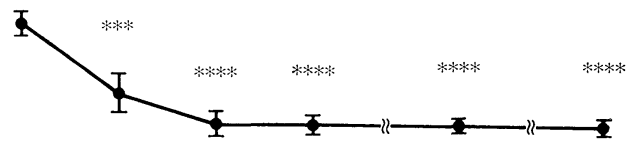

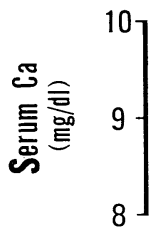

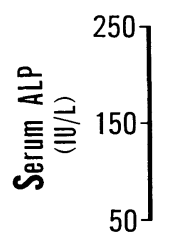

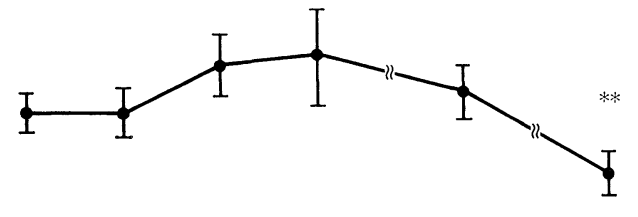

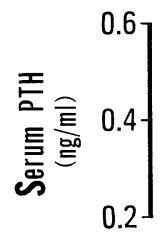
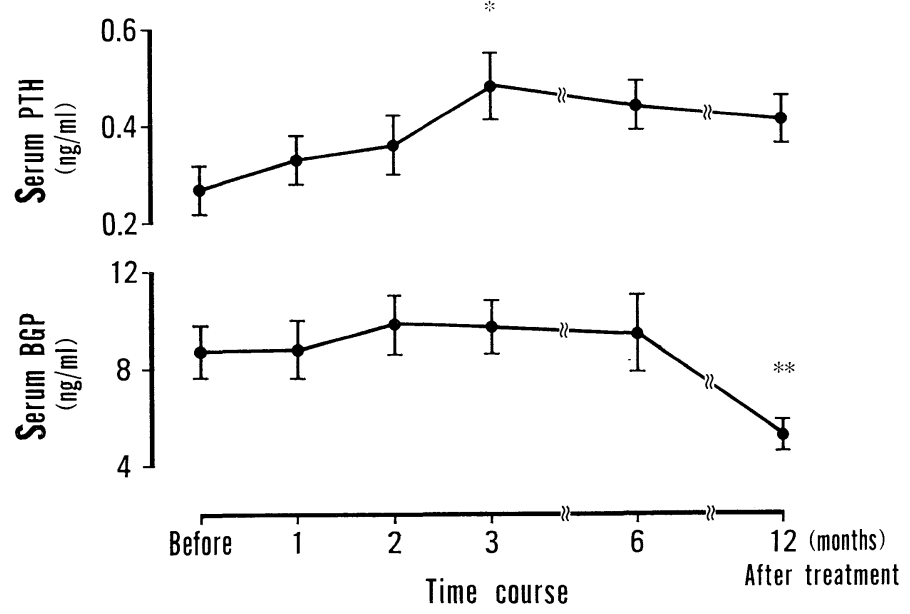

Fig. 3. Changes in serum $\mathrm{FT}_{3}, \mathrm{Ca}, \mathrm{ALP}, \mathrm{PTH}$ and BGP during methimazole therapy in eight patients with hyperthyrodism. *P $<0.05, * *<0.02, * * *<0.01$ and $* * * *<0.001$ vs the preadministration value. 


\section{$\mathrm{T}_{3} 75 \mu \mathrm{g} /$ day $\times 7$ days}

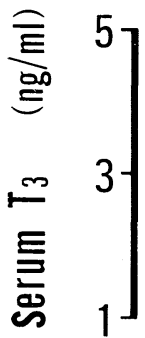

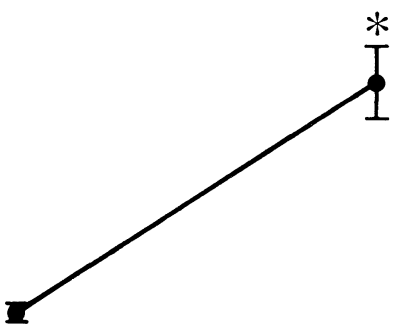

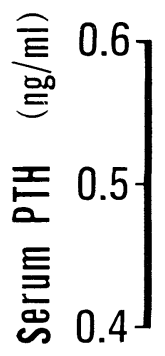

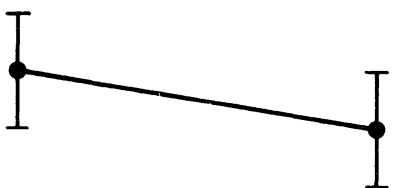

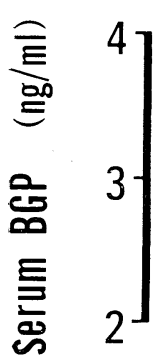

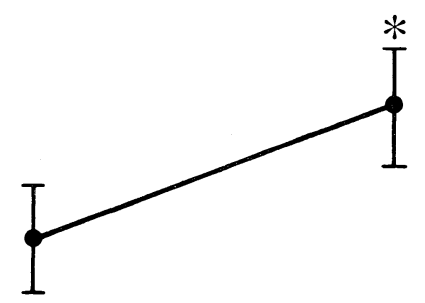

\section{Before}

Fig. 4. Changes in serum $\mathrm{T}_{3}, \mathrm{PTH}$ and BGP after treatment with triiodothyronine $(75 \mu \mathrm{g}$, daily) for $T_{3}$ suppression testing in 15 patients with remittent hyperthyroidism. $* \mathbf{P}$ $<0.001$ vs pretreatmient value.

( $p>0.001)$ from the pretreatment value of $2.7 \pm 0.38 \mathrm{ng} / \mathrm{ml}$ to $3.6 \pm 0.38 \mathrm{ng} / \mathrm{ml}$ at one week (Fig. 4). levothyroxine sodium $25 \sim 150 \mu \mathrm{g}$, daily
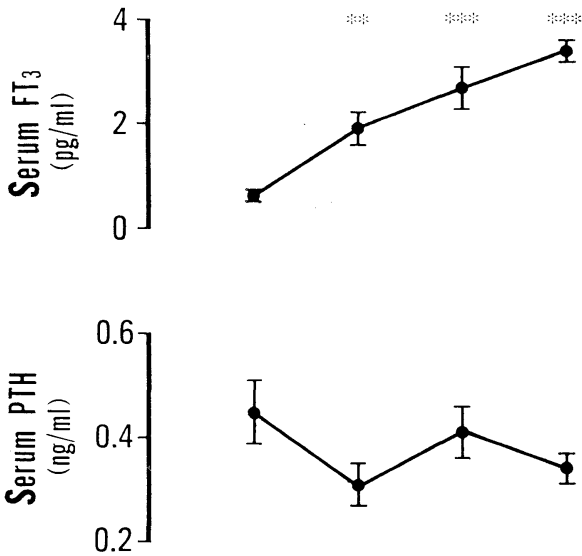

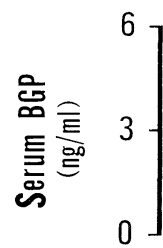
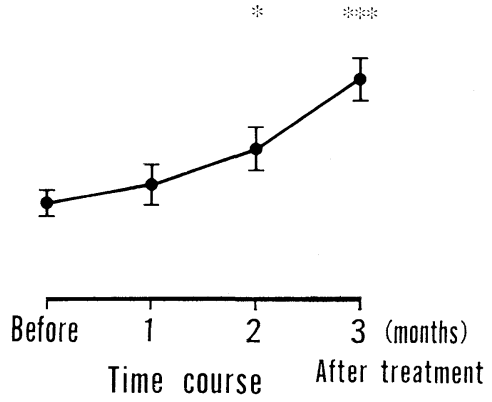

Fig. 5. Changes in serum $\mathrm{FT}_{3}$, PTH and BGP during levothyroxine (25-150 $\mu \mathrm{g}$, daily) therapy in nine patients with hypothyroidism. $* \mathbf{P}<$ $0.05, * *<0.005$ and $* * *<0.001$ vs pretreatment value.

Fig. 5 shows the changes in $\mathrm{FT}_{3} \mathrm{PTH}$, and BGP in the serum accompanying $T_{4}$ therapy in nine patients with hypothyroidism. Serum $\mathrm{FT}_{3}$ increased signficantly from the pretreatment value of $0.64 \pm 0.10 \mathrm{pg} / \mathrm{ml}$ to $1.9 \pm 0.31 \mathrm{pg} / \mathrm{ml}(\mathrm{p}<0.005)$ one month after treatment was started, $2.7 \pm 0.37 \mathrm{pg} / \mathrm{ml}$ $(\mathrm{p}<0.001)$ after two months and $3.4 \pm 0.21$ $\mathrm{pg} / \mathrm{ml}(\mathrm{p}<0.001)$ after three months. Serum PTH decreased from the pretreatment value of $0.45 \pm 0.05 \mathrm{ng} / \mathrm{ml}$ to $0.31 \pm 0.04 \mathrm{ng} / \mathrm{ml}$ one month after treatment was started, but no significant change was observed. Serum 
BGP increased significantly, closely paralleling the increases in serum $\mathrm{FT}_{3}$ from the pretreatment value of $1.3 \pm 0.37 \mathrm{ng} / \mathrm{ml}$ to $2.8 \pm 0.61 \mathrm{ng} / \mathrm{ml}(\mathrm{p}<0.05)$ two months after treatment was started and $4.8 \pm 0.53$ $\mathrm{ng} / \mathrm{ml}(\mathrm{p}<0.001)$ after three months.

\section{Discussion}

Serum BGP is thought to be a marker of bone turnover, particularly bone formation, in patients with metabolic bone disease such as primary hyperparathyroidism (Price et al., 1980; Delmas et al., 1983; Yoneda et al., 1986).

Recently the serum BGP concentration has been assayed in patients with thyroid malfunction and reported to be high in patients with hyperthyroidism (Orimo et al., 1983; Garrel et al., 1986; Lukert et al., 1986; Johansen et al., 1987). However, there are somewhat different views on the serum BGP concentration in patients with hypothyroidism: Nakai (1984) reported it to be high but Johansen (1987) reported it to be low.

In our study, the serum BGP concentration was abnormally high in many patients with hyperthyroidism, while it was abnormally low in many patients with hypothyroidism. These facts show that thyroid function seriously affects serum BGP. It is known that the synthesis and secretion of BGP in osteoblasts is stimulated by treatment with active vitamin $D$ (Price and Baukol, 1980). In patients with hyperthyroidism, however, parathyroid function is reduced (Bouillon and Moor, 1973; Mosekilde and Christensen, 1977), and serum vitamin $\mathrm{D}$ is also decreased (Velnentzas et al., 1977 ; Bouillon et al., 1980).

We had reported that the serum BGP concentration was high in patients with primary hyperparathyroidism and low in those with idiopathic hypoparathyroidism (Yoneda et al., 1985). In the present study, the parathyroid function was suppressed in the patients with hyperthyroidism, which supports the previous reports. Therefore, we have to seek the other causes for increased serum BGP.

The serum BGP concentration had a positive correlation with serum $\mathrm{FT}_{3}$ and $\mathrm{FT}_{4}$. Moreover, thyroid hormone increased serum BGP in a short time in the patients with remittent hyperthyroidism and in parallel to serum $\mathrm{FT}_{3}$ in the patients with hypothyroidism.

Rizzoli (1986) reported, using an in vitro system, that there are $T_{3}$ receptors in the nuclei of rat osteosarcoma cells and that $T_{3}$ directly accelerates the synthesis and secretion of BGP. These facts strongly suggest that thyroid hormone directly accelerates the synthesis and secretion of BGP in existent osteoblasts.

In the course of treatment of hyperthyroidism, the serum BGP concentration was normalized conspicuously more slowly than the serum $\mathrm{FT}_{3}$. This phenomenon is similar to the slow decrease in the BGP concentration after a parathyroid adenoma was removed from a patient with primary hyperparathyroidism (Delmas et al., 1986). The high serum BGP concentration in the patients with hyperthyroidism cannot be explained by the direct action of thyroid hormone alone. Other factors may also be involved. It is well known that thyroid hormone directly promotes bone resorption (Mundy et al., 1976; Orbai and Gozarium, 1982). The present study suggested that activation of bone resorption by thyroid hormone stimulates the bone remodeling cycle and enhances the number and activity of the osteoblasts. e. g. the activation of bone formation, and that this phenomenon lasts for a long term. However, in order to elucidate the mechanism, further study will be required on various factors involving the bone remodeling cycle.

These results indicated that, in vivo, thyroid hormones directly promote the 
synthesis and secretion BGP in existent osteoblasts and also stimulates the bone remodeling cycle by accelerating bone resorption: These acute and chronic actions increase serum BGP.

\section{References}

Bouillon, R. and P. DeMoor (1973) Parathyroid function in patients with hyper- or hypothyroidism. J. Clin. Endocrinol. Metab. 38, 999-1004.

Bouillon, R., Muls and P. DeMoor (1980). Influence of thyroid function on the serum concentration of 1,25-dihydroxyvitamin D. J. Clin. Endocrinol. Metab. 51, 793-797.

Delmas, P. D., H. W. Wahner, K. G. Mann and B. L. Riggs (1983). Assessment of bone turnover in postmenopausal osteoporosis by measurement of serum bone Gla protein. $J$. Lab. Clin. Med. 102, 470-476.

Delmas, P. D., B. Demiaux, L. Malaval M. C. Chapuy, C. Edouard and P. J. Munier (1986). Serum bone gamma carboxyglutamic acidcontaining protein in primary hyperparathyroidism and in malignant hypercalcemia. J. Clin. Invest. 77, 985-991.

Garrel, D. R., P. D. Delmas, L. Malaval and J. Tourniaire (1986). Serum bone Gla protein : A marker of bone turnover in hyperthyroidism. J. Clin. Endocrinol. Metab. 62, 1052-1055.

Johansen, J. S., J. E. M. Hansen and C. Chistiansen (1987). A radioimmunoassay for bone Gla protein (BGP) in human plasma. Acta Endocrinol. 114, 410-416.

Kawakubo, A., M. Kurokawa, M. Yoneda, S. Kawakita, K. Takatsuki and A. Tomita (1986). Basic and clinical studies on serum parathyroid hormone using the radio immunoassay kit "Yamasa". Horumon to Rinsho 34, 1065-1070 (In Japanese).

Kisamori, S., M. Hakamada, N. Fukuma, M. Funauchi, M. Ito, Y. Hirooka and N. Nihei (1984). Clinical significance of serum free triiodothyronine measured by radioimmunoassay. Igaku to Yakugaku, 12, 841-847 (In Japanese).

Lukert, B. P., J. C. Higgins and M. M. Stoskopf (1986). Serum osteocalcin is increased in patients with hyperthyroidism and decreased in patients receiving glucocorticoids. J. Clin. Endocrinol. Metab. 62, 1056-1058.
Mitsuma, T., S. Wanibe, K. Yamauchi, Y. Imai and N. Nihei (1976). Clinical evaluation of triiodothyronine radioimmunoassay $-\mathrm{T}_{3}$ RIAKIT II-. Horumon to Rinsho 24, 12971301 (In Japanese).

Mitsuma, T. and T. Nogimori (1981). Radioimmunoassay for free thyroxine in serum. Igaku to Yakugaku 5, 603-608 (In Japanese).

Mosekilde, L. and M. S. Christensen (1977). Decreased parathyroid function in hyperthyroidism: Interrelationships between serum parathyroid hormone, calcium-phosphorus metabolism and thyroid function. Acta Endocrinol. 84, 566-575.

Mundy, G. R., J. L. Shapiro, [J. G. Bandelin, E. M. Canalis and L. G. Raiz (1976). Direct stimulation of bone resortion by thyroid hormones. J. Clin. Invest. 58, 529-534.

Nakai R., H., Orimo, M. Harasawa. T. Tsutsumi, Y. Otawara, N. Hosoya and Y. Moriuchi (1984). Osteocalcin level in the plasma of normal subjects and patients with metabolic bone disease-Correlation between various serum parameters-. Jpn. J. Geriat. 21, 565572 (In Japanese).

Orbai, P. and L. Gozarium (1982). Effect of thyroid hormones on osteolysis "in vitro". Rev. Roum. Med. Endocrinol. 20, 181-185.

Orimo, H., R. Nakai, C. Sakaguchi, Y. Ohtawara, S. Moriuchi and K. Hosoya (1984). Role of osteocalcin in the pathophysiology of metabolic bone disease. Endocrine control of bone and calcium metabolism. P. 461, Editors Cohn, D. V., T. Fujita., J. T. Potts Jr. and R. V. Talmage, Excepta Medica, Amsterdam.

Payne, R. B., A. J. Little, R. B. Williams and J. R. Milner (1973). Interpretation of serum calcium in patients with abnormal serum proteins. Br. Med. J. 15, 643-646.

Price, P. A., J. G. Parthmore and L. J. Deftos (1980). New biochemical marker for bone metabolism. J. Clin. Invest. 66, 878-883.

Price, P. A. and S. A. Baukol (1980). 1,25dihydroxyvitamin D increases synthesis of the vitamin K-dependent bone protein by osteosarcoma cells. J. Biol. Chem. 255, 1166011663.

Rizzoli, R., J. Poser and U. Burgi (1986). Nuclear thyroid hormone receptors in cultured bone cells. Metabolism. 35, 71-74.

Velentzas, C., D. G. Oreopoulos, G. From, B. Porret and A. Rapoport (1977). Vitamin-D levels in thyrotoxicosis. Lancet 1, 370-371. 
Yoneda, M. and A. Tomita (1985). Osteocalcin. Horumon to Rinsho 33, 943-948 (In Japanese). Yoneda, M., K. Takatsuki, Y. Oiso, T. Takano, M. Kurokawa, A. Ota, A. Tomita, T. Ohno, K. Okano and T. Kanazawa (1986). Clinical significance of serum bone Gla protein and urinary $\mathrm{Gla}$ as biochemical markers in primary hyperparathyroidism. Endocrinol. Jpn. 33, 8994. 